$631.4(477.8)$

\author{
. озняк, О. онішко \\ ввівський н ціон льний університет імені в н \\ вул. . орошенк , 41, м. ввів, 79000, кр їн
}

ро н лізов но результ ти грунтово-геогр фічних досліджень хідного регіону кр їни, пов'яз ні з розробкою теоретичних і пр ктичних основ генези, геогр фії, кл сифік ції т екології грунтів, їхнім р ціон льним використ нням т охороною.

лючові слов : грунтозн вство, геогр фія грунтів, генез грунтів, екологія грунтів, хідний регіон кр їни.

всіх ет п х розвитку грунтозн вство утверджув лось як с мостійн н ук і формув ло уявлення про грунт як с мостійне природно-історичне тіло. ля суч сного періоду розвитку грунтозн вств і геогр фії грунтів х р ктерн підвищен ув г до глоб льних спектів світових проблем. чевидно, в жливим $є$ усвідомлення природних ресурсів, у тім числі грунтів і грунтового покриву як з г льного н дб ння людств , непричетного до яких-небудь держ вних і н ціон льних кордонів, які функціонують як єдин цілісн систем н поверхні пл нети. оці льні т екологічні проблеми, що стоять нині перед світовою спільнотою, зн чно сприяли утвердженню т визн нню істинності цього положення й необхідності дотрим ння його в н укових розробк х $\mathrm{i}$ пр ктичних з ход х. бруднення природного середовищ, у тім числі педосфери, глоб льні клім тичні зміни, дегр д ція грунтового покриву, нест ч продовольств - пом'якшення, г льмув ння і ліквід ція цих т інших нег тивних явищ потребують зн ння глоб льних 3 кономірностей і відповідних м сшт бних зрушень [21].

вітов грунтозн вч н ук м є в гомі н пр цюв ння в цьому н прямі в $p$ мк $\mathrm{x}$ міжн родних комплексних прогр м. дн к ре ліз ція цих розробок стик ється з об'єКтивними труднощ ми, серед яких н йчіткіше виділяється недост тність зн нь про з кономірності грунтового покриву світу, різном ніття грунтових і грунтово-геогр фічних н ціон льних шкіл, які ускл днюють вз єморозуміння спеці лістів. жливо з зн чити про тр диційну вузькість уч сті в цих розробк х предст вників укр їнської школи грунтозн вців і геогр фів, які м ють дост тньо оригін льні ідеї в г лузі генези і геогр фії грунтів.

озвиток н уки, зокрем грунтозн вств , продиктов ний з пит ми суспільств , використ ння н уково-пр ктичних розробок з лежить від рівня соці льно-економічного розвитку.

підст ві н лізу грунтово-геогр фічних досліджень хідного регіону кр їни можн стверджув ти, що з усіх природних компонентів у просторовому спекті н йдет льніше вивчені грунти. всі сільськогоспод рські землі й ч стково землі лісового

(C) озняк ., онішко ., 2012 
фонду скл дено грунтові к рти м сшт бу 1:10 000 і 1:25 000, які періодично поновлюють. роте ост нніми рок ми дослідження н уково-прикл дного н пряму скоротились.

лоефективним ст ло інформ ційне поле дослідження грунтів. нині грометеорологічні д ні по конкретних регіон х, які є дуже в жливими для н лізу й оцінюв ння грогрунтових умов вирощув ння сільськогоспод рських культур т вжиття гротехнічних і громеліор тивних з ходів. еликом сшт бні грунтові й грохімічні дослідження грунтів скорочені до мінімуму, в окремих регіон х ост нніми десятиріччями їх зовсім не проводили, оскільки н це потрібно зн чні кошти [22].

ирішенням кту льних проблем грунтозн вств і геогр фії грунтів хідного регіону кр їни з йм ються н укові, н уково-дослідні колективи, виробничі орг ніз ції, вищі н вч льні 3 кл ди. терен х хідного регіону кр їни сформув лися регіон льні школи грунтозн вств : львівськ (з поч тков н проф. . озняком), чернівецьк (з поч тков н проф. . 3 ренком), рівненськ (з поч тков н проф. . ознюком). ктивізув лись грунтово-геогр фічні дослідження у олинському н ціон льному університеті імені есі кр їнки, рик рп тському н ціон льному університеті імені силя теф ник, жгородському н ціон льному університеті, ьвівському н ціон льному гр рному університеті, нституті екології рп т кр їни, нституті землеробств і тв ринництв хідного регіону кр їни, риродозн вчому музеї кр їни, нститут х землеустрою, блдержродючість.

ст нніми десятиріччями головні н прями н уковців-грунтозн вців к федри грунтозн вств і геогр фії грунтів ьвівського н ціон льного університету імені в $\mathrm{H} \quad \mathrm{p} \mathrm{H}^{-}$ к , з снов ної 1993 р., пов’яз ні з розробкою теоретичних і пр ктичних основ генези, геогр фії, кл сифік ції т екології грунтів, фунд мент льними пит ннями екологічної ролі грунту в біосфері, p ціон льним використ нням грунтів т їхньою охороною, узгодженням кл сифік ційно-ді гностичних озн к і п р метрів грунтів відповідно до європейської і міжн родної кл сифік цій. уково-пр ктичні розробки орієнтов ні н екологічно безпечне використ ння ресурсного потенці лу грунту, обгрунтув ння екологічної стійкості грунтів, шляхів вирішення біологіз ції гроекосистем і грол ндш фтів, пл нув ння грунтово-протидегр д ційних з ходів, удоскон лення розміщення сільськогоспод рського виробництв з ур хув нням суч сного ст ну земельних ресурсів, проведення прикл дних досліджень з оптиміз ції поживного режиму грунтів під різні сільськогоспод рські культури, ерозійної дегр д ції грунтів, розроблення з ходів з р ціон льного використ ння й охорони еродов них і меліоров них земель, відновлення контурно-меліор тивних систем землеробств тощо.

жливе теоретико-методологічне зн чення в грунтозн встві м $є$ поняття про х р ктерний ч с грунтових процесів (ч с, необхідний для уст лення рівнов ги грунту чи його окремих вл стивостей з чинник ми природного середовищ ). рямих визн чень швидкості розвитку окремих процесів м ло. прямов ність, х р ктер і швидкість процесу грунтотворення визн ч ють чинники зовнішнього середовищ . о них н лежить і т кий в жливий чинник, як нтропогенний. ін діє р зом з природними чинник ми, проте істотно відрізняється від них, н с мперед, він, з звич й, є зн чно інтенсивнішим [24].

ослідження . озняк з свідчили, що в ході зрошення чорноземів у грунтово-підгрунтовій товщі змінюються не тільки грунтові, й л ндш фтно-геохімічні процеси, інтегр льним пок зником яких буде і л ндш фт, і грунт, декв тні новим умов м зволоження. і суч сні процеси м ють різну спрямов ність і швидкість, тобто різний х р ктерний ч с, з який процес, озн к чи вл стивість н йінтенсивніше змінюються під 
впливом зміненого чинник середовищ доти, доки не уст литься рівнов г з цим чинником, і н д лі розвиток у цьому н прямі бо припиняється, бо колив ється біля середнього зн чення, бо відбув ється симптотично [23].

рошення чорноземів ктивізує як швидкоплинні, т к і трив лі процеси. дослідження суч сних грунтотворних процесів у зрошув них чорнозем х півдня кр їни свідч ть, що швидко змінюються кислотно-основні й окисно-відновні режими, вологість, темпер тур , скл д грунтових розчинів, тр нсформ ція і мігр ція форм зоту і фосфору тощо. о стосується процесів, трив лість яких вимірюється десятк ми, сотнями, тим більше тисяч ми років (формув ння сольового профілю грунтово-підгрунтової товщі, фізичного, к рбон тного, гумусового, мінер логічного профілів, звітрюв ння первинних мінер лів), то можн лише визн чити тенденцію їхього розвитку. ричин цього - несумірність терміну зрошення в чорнозем х степової зони з трив лістю суч сних грунтотворних і л ндш фтно-геохімічних процесів [23].

ивчення суч сних процесів у чорнозем х помірної і холодної ф цій, викон не . видницьким, довело, що ф ці льні чинники вплив ють головно н трив лість періоду, протягом якого зміни вл стивостей і режимів чорноземів під впливом зрошення н був ють кв зірівнов жного ст ну з новими умов ми середовищ . ля чорноземів холодної ф ції цей період ст новить 30 років, для чорноземів помірної ф ції - 15 років [29].

ст нніми рок ми в н уковій літер турі інтенсифікув лось обговорення пит нь теорії грунтотворення в 3 пл в х рік. енезу з пл вних грунтів розгляд ють 3 погляду співвідношення геологічного і біологічного колообігів у процесі грунтотворення. цього погляду н йз г льніш і н йв гоміш особливість грунтотворення в 3 пл в х рік поляг $є$ в тому, що м лий біологічний колообіг елементів живлення рослин розвив ється в них н тому відрізку великого геологічного колообігу, де зосереджене перенесення цих елементів, не втягнутих у біологічний колообіг н вододіл х і тер с х.

пл в є особливим елементом л ндш фту, для якого х р ктерне виняткове різном ніття умов життя, велик строк тість у просторі і швидк мінливість у ч сі. ідповідно до цього, конкретні форми прояву з г льних особливостей з пл вного грунтотворення т кож різном нітні. різних ч стин х з пл ви н стільки по-різному відбув ються процеси колообігу речовин, неодн ковий водно-повітряний режим грунтів, їхня будов і вл стивості, що можн говорити про різні типи з пл вних грунтів.

н ліз особливостей з пл вного грунтотворення і х р ктеристик люві льних з пл вних грунтів р. хідний уг н ведені в публік ціях . конечного, який з зн ч $\epsilon$, що в ділянці прируслової з пл ви формуються дернові з пл вні грунти, для центр льної ч стини з пл ви х р ктерні лучні з пл вні, які формуються під впливом лучного процесу грунтотворення. учно-болотні т болотні з пл вні грунти приурочені до притер сної ч стини з пл ви. ідмінності в грунтотворенні т вл стивостях грунтів прируслової, центр льної і притер сної ч стин з пл ви зумовлюють різний х р ктер їхнього використ ння. скільки з пл в ріки - це н йкр щі природні кормові угіддя, то люві льні грунти використовують здебільшого як високопродуктивні сінокоси т п совищ [13].

іоклім тичні умови території спричиняють просторову внутрішньоф ці льну диференці цію пок зників морфометрії, фізичних і фізико-хімічних вл стивостей грунтів.

хідноукр їнський кр й є дуже специфічним природним регіоном вропи в пл ні формув ння перехідної грунтово-л ндш фтної структури від типово лісостепової східноєвропейської з домінув нням у структурі грунтового покриву типових і опідзолених чорноземів, до лісо-лучної центр льноєвропейської з невеликою ч сткою чорноземів серед зн чних м сивів сірих лісових грунтів. $\mathrm{p}$ ктерною регіон льною рисою чорно- 
земів $з$ хідноукр їнського кр ю, як визн ч є х р ктер їхнього профілю, його морфологію і, як н слідок, формув ння специфічних вл стивостей чорноземів вологої тл нтичної ф ції, $є$ їхня приуроченість до порід лесової форм ції з хідноукр їнського типу, включ ючи еолові елюві льно-делюві льні леси і лесоподібні суглинки, делюві льні, флювіогляці льні т д вньо люві льні оглеєні лесоподібні суглинки. крім того, чорноземи 3 хідноукр їнського кр ю трив лий ч с формув лися в умов х домінув ння лісо-лучних л ндш фтів н д типово степовими, з розвиненою моз їчною л ндш фтною структурою перехідного типу, що зн йшло пряме відобр ження в хіміко-мінер логічному, гр нулометричному, гумусовому, к рбон тному профілі чорноземів. н шому рсен лі є щор з більше док зів н користь лісової генези чорноземів опідзолених хідного оділля і ридністер'я, особливо н оглеєних безк рбон тних лесоподібних суглинк х пілля $\mathrm{i}$ янсько- ністерської височини. ез глибокого розуміння природи досліджув них чорноземів, історичних спектів їхнього ст новлення т еволюції, причин і мех нізмів дегр д ції неможливе відродження чорноземів як ет лон родючості в умов х суч сних л ндш фтів.

ч с екстенсивного використ ння чорноземів з'явилися небезпечні тенденції, що 3 грожують повною їхньою дегр д цією, втр тою в жливих екост білізув льних біосферних функцій. же не можн говорити про дегр д цію чорнозему в однині, оскільки вон охопил пр ктично всі скл дові м тричної орг ніз ції грунту, включно 3 хіміко-мінер логічним скл дом, який донед вн вв ж ли консерв тивною, стійкою до змін ч стиною чорноземів.

озм х нег тивних явищ у чорнозем х н стільки великий, що породив глибоку всеохопну кризу сільськогоспод рського виробництв, що може перерости в к т строфу. ї легко прогнозув ти, проте в жко спинити. од льші н укові дослідження чорноземів можуть допомогти подол ти цю екологічну і соці льну к т строфу, оскільки основні в желі ії подол ння зосереджені в с мому чорноземі: першокл сній хіміко-мінер логічній основі, к рк сній орг ніз ції мінер льної т орг нічної м триці, стр тифік ції н генетичні горизонти. сі ці спекти потребують дет льних досліджень н різних рівнях структурно-ієр рхічної орг ніз ції чорнозему, почин ючи від том рного і з кінчуючи просторово-територі льним.

хідному регіоні кр їни н йпродуктивніші сільськогоспод рські угіддя і н йстійкіші гроекосистеми приурочені с ме до різних видів чорноземних грунтів. фективне функціонув ння чорноземів в грол ндш фт х, їхня охорон $\mathrm{T}$ відтворення родючості неможливі без дет льних досліджень чорноземів н всіх структурно-функціон льних рівнях [18].

кту льною проблемою є вивчення дин міки суч сних грунтотворних процесів у грунт х ередк рп ття, які інтенсивно використовують у сільському господ рстві. ослідженнями . нььків виявлено, що основні ре ли дерново-підзолистих поверхневооглеєних грунтів приурочені до четвертої н дз пл вної тер си і фр гмент рно тр пляються н підвищених ділянк $\mathrm{x}$ другої тер си в комплексі з лучними, дерновими глейовими грунт ми. підст ві результ тів в лового хімічного н лізу т якісного скл ду гумусу обгрунтов но ді гностичні критерії перев жних грунтотворних процесів: опідзолення (молекулярне відношення $\mathrm{SiO}_{2} / \mathrm{Al}_{2} \mathrm{O}_{3}$, елюві льно- кумулятивні коефіцієнти оксидів, пок зники зміни силік тної ч стини, б л нси оксидів і мулу); елюві льноглейовий процес (пок зники молекулярних відношень $\mathrm{Al}_{2} \mathrm{O}_{3} / \mathrm{Fe}_{2} \mathrm{O}_{3}$, порівняння витр т $\mathrm{Fe}_{2} \mathrm{O}_{3} \mathrm{i} \quad \mathrm{Al}_{2} \mathrm{O}_{3}$ ); дернового (відношення г.к.: ф.к., вміст фр кцій -2 , відношення : $\quad$ у другій фр кції гумусових речовин). 
морфології досліджув них грунтів виявлено формув ння фр джипену в нижній ч стині ілюві льного горизонту вн слідок процесів ущільнення, яке зумовлене чергув нням реліктових процесів 3 мерз ння і відт юв ння, що спричинило соліфлюкцію верхніх і ущільнення нижніх горизонтів. ля горизонту х р ктерні інтенсивне реліктове оглеєння, брилув т структур , високі пок зники щільності будови, низьк пл стичність. 'ясов но, що в процесі сільськогоспод рського освоєння відбулося зміщення процесу опідзолення у верхню ч стину ілюві льного горизонту т посл блення інтенсивності елюві льно-глейових процесів. підст ві розр хунку б л нсу оксидів і мулу виявлено, що перев жн більшість їх виноситься з межі грунтового профілю і тільки близько $10 \%$ кумулюється у нижній ч стині ілюві льного горизонту [15].

ивчено геогр фічні з кономірності поширення буроземно-підзолистих глейових грунтів, які окремими ре л ми тр пляються в меж х п'ятої-шостої тер с т сформув лися н делюві льних суглинк х 3 умов н длишкового зволоження т промивного водного режиму під дубово-ялицевими ліс ми з глибокого з ляг ння грунтових вод, т підзолисто-дернових грунтів, які приурочені до реліктових притер сових знижень у меж х другої-четвертої н дз пл вних тер с.

підст ві вивчення регіон льних особливостей землекористув ння в меж х $\mathrm{p}$ п тського регіону кр їни з пропонов но виділення кл сифік ційних к тегорій землекористув ння (типи і форми), принципи т підходи до дослідження землекористув ння (пр вові, територі льні, екологічні, економічні), які д ють змогу визн чити ефективність і доцільність різних н прямів використ ння земельних ресурсів, вивчено особливості землекористув ння в різні історичні періоди в хідному регіоні кр їни [16].

плив інтенсивного сільськогоспод рського використ ння н дин міку суч сних грунтотворних процесів у рендзин х лого олісся досліджув в . ирильчук. 'ясов но, що тр нсформ ція елемент рних грунтотворних процесів змінює їхню швидкість і спрямов ність, спричиняє нег тивні тенденції в дин міці основних грунтових вл стивостей і режимів. освоєних дерново-к рбон тних грунт х (рендзин х) домінують т кі елемент рні грунтотворні процеси: дерново- кумулятивний, розчинення і вилуговув ння к рбон тів (як один з н слідків внутрішньогрунтового вивітрюв ння), гумусон копичення, дез грег ція грунтової м си, як поляг є в руйнув нні структури орного т підорного горизонтів, ущільненні грунтового профілю. міни в спрямов ності $\mathrm{T}$ x p $\mathrm{k}$ тері елемент рних грунтотворних процесів в освоєних дерново-к рбон тних грунт х ведуть до зміни їхніх морфологічних і гровиробничих вл стивостей, вплив ють н продуктивність [8].

продовж декількох ост нніх років (2008-2011) проводять дет льні грунтово-геогр фічні дослідження сл бкорозвинутих рендзинних грунтів у різних геоморфогеннофітоценотичних умов х урочищ іл гор $\mathrm{T}$ техногенно порушених рендзин штучно створених тер сових комплексів у меж х ороняцького природного $\mathrm{p}$ йону хідноподільської височинної обл сті хідноукр їнського кр ю. 'ясов но, що формув ння генетичного профілю сл бкорозвинутих рендзинних грунтів відбув ється під впливом біогенно- кумулятивних процесів грунтотворення, серед яких визн ч льну роль відігр ють підстилкоутворення і дерновий процес. одноч с перев жними елемент рними процес ми грунтотворення у техногенно порушених рендзин х штучно створених теp сових комплексів є педотурб ційні (дин моморфні) т нтропогенні процеси [9].

лежно від того, н скільки декв тно грунт відобр ж є середовище, розгляд ють еволюцію стир льну (всі сліди попередніх ст дій грунтотворення стерті), розвив льну (профіль розвив ється у колишньому н прямі), н кл дену (у профілі н явні сліди всіх 
ст дій грунтотворення) і усп дковув льну (профіль зберіг ється без змін зі зміною х p ктеру грунтотворення). в жливості цих положень необхідно н голосити особливо в зв'язку з вивченням структури грунтового покриву.

ході дослідження умов диференці ції грунтового покриву ологоро- ременецького горбогір'я т формув ння його структури з'ясов но, що серед грунтових комбін цій перев ж ють поєдн ння і в рі ції, менше - поєдн ння-моз їки і т шети. оловними чинник ми формув ння структури грунтового покриву є вплив геолого-геоморфологічних і гідрогеологічних умов. иявлено, що середні площі т коефіцієнт розчленув ння елемент рних грунтових ре лів з леж ть від ступеня еродов ності грунтів: зі збільшенням рівня еродов ності середні площі ре лів зменшуються, коефіцієнти розчленув ння зрост ють. формув ння неоднорідності грунтового покриву суттєво вплив ють процеси водної ерозії. 30-річний період сільськогоспод рського використ ння зменшил сь сум рн площ нееродов них грунтів, т кож середня площ їхніх ре лів, зросли ступінь мінливості, коефіцієнти скл дності, контр стності т неоднорідності грунтового покриву. умов под льшого інтенсивного розвитку ерозії в меж х ологоро- ременецького горбогір'я збережеться тенденція до зрост ння кількості дрібних контр стних грунтових комбін цій, хоч нині т м перев ж ють крупноблокові н півконтр стні [7].

підст ві н лізу генетико-геометричної будови елемент рних грунтових ре лів олинської височини, виявлено тенденцію до збільшення середніх площ ре лів з лежно від типів грунтів: від сірих лісових грунтів до чорноземів опідзолених і регр дов них. иявлено зменшення розмірів контурів від сл бко змитих до сильнозмитих. грунтовому покриві олинської височини чинники диференці ції зумовлюють перев ж ння висотно-диференційов них контр стних дрібнорозчленов них і крупноблокових розчленов них в рі цій т поєдн нь сірих лісових, темно-сірих опідзолених, чорноземів опідзолених, лучно-чорноземних, лучних грунтів, які формують деревоподібну (ерозійну) структуру грунтового покриву [26].

ст нніми рок ми в грунтозн встві н мітився новий н прям - екологічний. жливість екологічних пит нь у н уці про грунт визн чен н с мперед тією скл дною і 6 г тогр нною роллю, яку відігр є грунт у розвитку і функціонув нні окремих екосистем суші й з г лом біосфери.

дним із перспективних н прямів розвитку вчення про екологічні функції грунтів $\epsilon$ розробк теоретичних і прикл дних з с д визн чення якості грунтів як ст білізув льного чинник функціонув ння природних і гемеробних (окультурених) екосистем. еоретичні т методологічні з с ди екологічної якості сірих лісових грунтів гемеробних (окультурених) екосистем розроблені з ур хув нням їхньої зд тності до ре ліз ції екологічних функцій.

роблем якості сірих лісових грунтів особливо кту льн , оскільки ці грунти 3 ед фічним комфортом не відповід ють потреб м основних сільськогоспод рських культур. б'єктивн оцінк широкого спектр екологічних функцій грунту і пошук індик торів, які визн ч ють його ст н як біокосного тіл 3 умов гемеробії, пінь впливу н суміжні сфери - тмосферу і гідросферу, є н дзвич йно скл дною і в жливою. К оцінк д сть змогу не тільки екологізув ти суч сні схеми з стосув ння 3 собів громенеджменту і вирішити проблеми теорії т пр ктики використ ння сірих лісових грунтів, й пізн ти глибинні мех нізми функціонув ння грунту як симбіотрофного комплексу грунт-рослин - в жливої л нки орг ніз ції біосфери [3]. 
ізном нітними і дуже в жливими є глоб льні біосферно-екологічні функції грунтів, що зн чно зумовлене впливом біохімічних грунтових процесів н скл д і режим тмосферного повітря, грунтових і поверхневих вод, розвиток і продуктивність живих орг нізмів. собливо кту льний сьогодні біохімічний н прям розвитку грунтозн вств , що зумовлене посиленням процесу з бруднення біосфери т перетворенням його в глоб льний процес.

колі н укових біогеохімічних інтересів є г логеохімічн проблем . кр їні це особливо стосується території ричорноморсько- ри зовського сухостепового кр ю. омплексний підхід до вирішення педог логеохімічних проблем, розробки систем тики л ндш фтно-геохімічних комплексів півдня кр їни отрим ли зн чний розвиток у н укових пр цях . ривульченк , . ригуб т ін.

. ривульченко обгрунтув в н уковий н прям - педог логеохімію, який м є певну внутрішню структуру т необхідні н укові трибути і $є$ скл довою н укового н пряму г логеохімії. підст ві розробленої систем тики л ндш фтних комплексів півдня кр їни викон но л ндш фтно диференційов ний педог логеохімічний н ліз регіону, доведено н явність прояву л ндш фтно-педог логеохімічної широтної зон льності, силової мікрозон льності т різном ніття, т кож содопрояву і перев ж ння в ш рі 01 м нез солених і перехідних типів з соленості. омінуючим трендом у х р ктері 3 соленості грунто-підгрунтя регіону є розсолення, подекуди - уст лення дин мічної рівнов ги т вторинного з солення [12].

ослідження з виявлення територій із з брудненням грунтів в жкими мет л ми 3 свідчили, що в жливе місце в цих дослідженнях посід $є$ фтор як один з н йпоширеніших елементів у природі. собливого зн чення н були дослідження вмісту і мігр ції фтору в системі грунт-рослин у зв'язку з використ нням фосфорних добрив і проведенням хімічної меліор ції солонцюв тих грунтів відход ми хімічної промисловості фосфогіпсом.

еогр фічні з кономірності поширення і дин мік фтору в чорнозем х івнічно- хідного ричорномор'я висвітлені в пр цях . ригуб. 'ясов но, що вміст фтору в грунт х, його н дходження в рослини і грунтові води зумовлене гр нулометричним і мінер логічним скл дом, вмістом гумусу і к рбон тів, зн ченням р . иявлено з кономірне збільшення вмісту фтору у верхніх горизонт х грунтів від елюві льних до тр нселюві льних і кумулятивних л ндш фтів. рошення і хімічн меліор ція є в гомим чинником диференці ції території з вмістом в лового і водорозчинного фтору в грунт х. явність техногенно з бруднених фтором грунтів, що виявляється в м ксим льному н копиченні в лових і особливо водорозчинних форм фтору, зумовлен функціонув нням підприємств хімічної промисловості, зокрем , 3 виробництв фосфорних добрив, н відст ні 7-10 км від об'єкт [31].

уч сне грунтозн вство спрямов не н розкриття мех нізмів грунтотворення і розуміння з конів функціонув ння грунтового профілю. умусові речовини що н леж ть до основних компонентів грунтового профілю, вплив ють н широкий спектр природних і нтропогенних процесів у зоні гіпергенези: звітрюв ння мінер лів, іммобіліз цію і тр нспортув ння елементів, сорбцію пестицидів, формув ння грег тної структури т іонообмінних вл стивостей.

ивчення широкого спектр пок зників гумусового ст ну досліджув них грунтів смового обужжя д ло змогу . ідв льній виявити геогр фічні з кономірності зміни гумусу в різних підтип х грунтів, визн чити з лежність фізичних, морфологічних, фізико-хімічних вл стивостей грунтів від їхнього гумусового ст ну. ослідження вміс- 
ту т 3 п сів гумусу в різних підтип х сірих лісових і опідзолених грунтів смового обужжя підтвердило їхне підпорядкув ння з г льній геогр фічній з кономірності гумусоутворення: н йвищі пок зники вмісту т з п сів гумусу х р ктерні для чорноземів опідзолених, зн чно знижуються їхні зн чення в ясно-сірих грунт х. смове обужжя є р йоном д вньої культури землеробств . рив ле інтенсивне сільськогоспод рське освоєння грунтів позн чилося н їхніх вл стивостях. культурення ясно-сірих лісових грунтів привело до збільшення потужності гумусово-елюві льного горизонту т інтенсивності його сірого з $б$ рвлення, підняття глибини з ляг ння к рбон тів, зменшення процесу опідзолення. орному ш рі сірих лісових грунтів знизився вміст гумусу, проте грономічно якість гумусу в цих грунт х є вищою, що підтверджене високими пок зник ми ре кційної зд тності гумусу. н слідок сільськогоспод рського освоєння грунтів збільшується гум тність гумусу, вміст гумінових кислот, зв'яз них з к льцієм, зменшується диференці ція гумусового профілю 3 якісним скл дом гумусу. н слідок окультурення грунтів зменшил сь кількість бічних л нцюгів, збільшився ступінь ром тиз ції ядр гумінових кислот, отже, ст л кр щою структуров ність молекул. ерев ж ння фульвокислот у скл ді гумусу верхніх горизонтів ясно-сірих і сірих лісових грунтів під лісом є причиною їхньої високої кислотності: сільськогоспод рське освоєння грунтів спричинило зн чне зниження кислотності. иявлено тенденцію зрост ння вмісту гумусу в ясно-сірих і сірих лісових грунт х смового обужжя 340 років. темно-сірих опідзолених грунт х і в чорнозем х опідзолених сформув вся позитивний б л нс гумусу, причому не лише в орному, й у глибших горизонт х грунтового профілю, що свідчить про уст лення рівнов жного ст ну грунтів з природно- нтропогенними умов ми [19].

умов х щор з в жливішої ролі нтропогенного чинник в перетворенні грунтів проблем системного керув ння їхньою родючістю н був $є$ пріоритетного зн чення.

p ктер керув ння елемент ми родючості з лежить від ступеня вир ження грунтовобуферних мех нізмів. ослідження генези високої кислотності буроземів кр їнських

рп т, їхньої буферної зд тності до можливих кислотних впливів, ст ну кислотноосновних буферних систем є обов'язковим ет пом н шляху розробки теорії стійкості екосистем, т кож ступеня екологічного ризику, передусім з повідних територій, до щор з більших нтропогенних н в нт жень кислотного х р ктеру [4].

н чний нтропогенний вплив призводить до поширення дегр д ції грунтів. ослідженнями - шевлоцького, проведеними в меж $\mathrm{x}$ хідноукр їнської провінції ісостепу в обл сті олинської височини н території ок льського п см , виявлено, що 6 г товікове освоєння чорноземів типових і опідзолених, темно-сірих опідзолених і сірих лісових грунтів спричинило тр нсформ цію морфологічних озн к, фізичних і фізико-хімічних вл стивостей, що сформув ло особливий культурний грунтотворний процес і грогенну еволюцію грунтів.

Йк рдин льніших змін з зн ли пок зники, що х р ктеризують гумусові горизонти. ростежується збільшення їхньої потужності порівняно з цілинними грунт ми, змінюється з $б$ рвлення, гр нулометричний скл д, щільність будови, х р ктер переходу між генетичними горизонт ми. н слідок трив лого використ ння сірих і темно-сірих опідзолених грунтів відбув ється змін їхніх фізичних вл стивостей, що виявляється в дегр д ції структурного ст ну і зменшенні вмісту грономічно цінних мезо грег тів, збільшенні щільності будови, зменшенні з г льної шп рув тості, водопроникності. рив ле розорюв ння спричинило тр нсформ цію гумусного ст ну, скл ду вбирних основ, кислотно-основних вл стивостей тощо. окультурених сірих і темно-сірих 
опідзолених грунт х 3 фіксов но тренд у бік грунтів вищого т ксономічного р нгу 3 збереження їхніх основних генетичних озн к н родовому і видовому рівнях [25].

. мелинець, проводячи просторовий н ліз дегр д ційних процесів у сірих лісових грунт х хідного регіону кр їни з використ нням -технологій, розробив ф ктологічні т прогнозув льні ді гностичні критерії і пок зники. допомогою основних ф ктологічних ді гностичних озн к і вл стивостей проведено оцінку дегр д ції сірих лісових грунтів. . мелинець дослідив х р ктер і прояв ерозійних процесів т про н лізув в просторові особливості їхньої зміни. осліджув ні грунти м ють високий рівень дегр д ції. с мперед, це грофізичн дегр д ція, зокрем , ущільнення грунту і зменшення кількості грономічно цінних грег тів. цими критеріями ст н досліджув них грунтів є передкризовим бо кризовим. одноч с інтенсифікуються т кож ерозійні процеси, які призводять до зменшення вмісту гумусу і потужності гумусово-елюві льного горизонту [33].

икорист ння т ких -методів, як оверлейновий н ліз, геост тистик i просторових змін, д ло змогу обчислити і візу лізув ти к ртосхеми потенційно можливих проявів ерозійних процесів 3 геоморфологічними умов ми. 6 зі -середовищ Arc WIEW 3.2 створено -модуль Erision RUSLE - результ т повної інтегр ції універс льної емпіричної моделі модифіков ного універс льного рівняння ерозійних втр т грунту (Revised Universal Soil Loss Equation - RUSLE) у [32].

ст нніми десятиріччями зн чної шкоди грунтовому покриву хідного регіону кр їни з вд є використ ння систем м гістр льних трубопроводів. н ліз н укових досліджень свідчить про недост тній рівень вивчення впливу будівництв т експлут ції трубопроводів н грунтовий покрив. ослідженнями . елегуз, що проведені в меж х тр с м гістр льних трубопроводів “ ружб”'і дес - роди, з'ясов но геогр фогенетичні особливості тр нсформ ції грунтів, які поляг ють у формув нні специфічних техноземів, турб ційних і модифіков них, з лежно від розт шув ння трубопроводу в меж х певного л ндш фту. одо генетичних особливостей, то тр нсформ ція грунтів у меж х тр с м гістр льних трубопроводів відрізняється в технозем х модифіков них і турб ційних. изн чено кількісні т якісні пок зники, оцінено ступінь техногенної тр нсформ ції грунтів. ет льне дослідження морфологічної будови, вл стивостей грунтів у меж х тр с трубопроводів д ло змогу виявити в них суттєві зміни, що сформув ло специфічні техногенні грунти - техноземи, які є х отичною сумішшю м тері лу різних генетичних горизонтів і м теринської породи. технозем х, які використовують трив лий ч с як ріллю, простежується деяк ст біліз ція морфологічної будови, що поляг є в гомогеніз ції орного горизонту т поліпшенні його структурного ст ну. мінюються і фізичні вл стивості грунтів, що зумовлено впливом в жкої будівельної техніки т інтенсифік цією процесів ілімериз ції. ізко змінився х р ктер розподілу гумусу з глибиною. фіксов но незн чне зменшення вмісту гумусу в орних горизонт х техногенно модифіков них грунтів і зн чне зменшення в технозем х [30].

сушув льні меліор ції є одним з н йвідчутніших і р дик льних впливів н грунти і грунтовий покрив. ослідженнями . ськевич визн чено, що осушення і н ступне окультурення грунтів лого олісся суттєво посл блює процеси гідролізу і глеєутворення, посилює лесив ж, вплив $є$ н інтенсивність дернового процесу грунтотворення. есив ж у дерново-підзолистих грунт х лого олісся зумовив розтягув ння гумусового профілю, зменшення потужності бо руйнув ння елюві льного горизонту. лучних і дернових грунт х з трив лий період осушення з фіксов но незн чне лесивув ння, що позн чилося н морфологічних особливостях і виявляється в незн чному змен- 
шенні ступеня диференці ції профілю з вмістом мулу і розтягув нні гумусового т перехідного горизонтів грунтів. осушених грунт х сформув вся с мостійний, відмінний від природного культурний процес грунтотворення. сушення і сільськогоспод рське використ ння спричинило розвиток дегр д ційних процесів [5].

озроблено теоретичне обгрунтув ння розвитку дегр д ційних процесів у грунт х

лого олісся, сх р ктеризов но їхні причини і н слідки, модифіков но кл сифік цію дегр д ційних процесів н рівні типів і видів, з пропонов но семиступеневу шк лу оцінки типів і видів дегр д ції грунтів, т кож розроблено інтегр льну шк лу оцінки дегр д ції грунтів з г лом. осліджено пірогенну гр нулометричну дегр д цію і дегр д цію структури грунтового покриву. ля оцінки ст ну структури грунтового покриву з пропонов но пок зник - індекс розг луженості контурів рк.

торфово-болотних грунт х і торфовищ х низинних смового обужжя, дехівського і тинського природних р йонів пірогенн дегр д ція спричиняє глибокі деструкції в профілі торфових грунтів і в структурі грунтового покриву, є одним з н йнебезпечніших проявів дегр д ції грунтів.

інтегр льною оцінкою дегр д ції високого (кризового) рівня н йбільше підд ються грунти н смовому обужжі, дехівському, ідподільському, тинському, менше - усько- родівському і епетівському природних р йон х. кл дено к рту інтегр льної дегр д ції грунтів лого олісся [6].

еликі $з$ м сшт 6 ми осушув льні меліор ції і пов'яз не з цим сільськогоспод рське освоєння території хідного олісся кр їни спричинили розвиток нег тивних процесів: щор з більшу ден тур цію природного середовищ, прискорене розкл дення торфу в осушених торфовищ х, зменшення болотних т водних видів рослин і тв рин, з бруднення поверхневих і підземних вод нітр т ми, в жкими мет л ми, продукт ми розкл дення торфу т іншими речовин ми. ослідженнями . ов льця виявлено, що під впливом осушення н йінтенсивніші зміни відбув ються в поверхневих горизонт х дерново-середньопідзолистих глеєвих супіщ них грунтів, що зумовлено приорюв нням до гумусового горизонту ч стини елюві льного, змінюється з $б$ рвлення, утворюється грудкув т нетривк структур , збільшується ступінь ущільнення, у нижній ч стині орного і в елюві льному горизонт х інтенсифікуються процеси оглеєння, що вир ж ється збільшенням кількості $\mathrm{Fe}-\mathrm{Mn}$ конкрецій, вохристих плям. люві льно-ілюві льний горизонт осушених грунтів х р ктеризується грудкув то-пл стинч стою структурою, н явністюFе-Mn бобовин і плям сегрег цій [11].

еоретичн думк грунтозн вств ост нніх трьох десятиліть головно бул присвячен зовнішнім функціям грунтового покриву і грунтів. грунтозн встві відомий і широко використовув ний принцип вивчення грунту як ієр рхічного природного тіл . ля оцінки стійкості грунтів і грунтового покриву як iєp рхічної системи до природних і нтропогенних тр нсформ цій в жливою є кількісн оцінк мінливості н кожному рівні ієр рхії т їхнє співвідношення.

н ліз генетико-геогр фічних особливостей фізичного ст ну грунтів ередк рп ття н м кро грег тному і профільному рівнях д в змогу виявити, що зміни фізичних вл стивостей грунтів ередк рп ття відбув ються головно в процесі їхнього сільськогоспод рського використ ння. тупінь розпушення верхніх горизонтів грунтів порівняно 3 грунтотворною породою є виявом процесів переущільнення, брилоутворення, твердості грунтових м кро грег тів. підст ві порівняння пок зник ступеня розпушення різних 3 генетичною природою фонових грунтів ередк рп ття · ом нів розробив шк лу оцінки ступеня розпушення суглинкових і глинистих грунтів. пок зник ми 
критичної щільності верхні горизонти грунтів переущільнені. ивчення щільності будови, шп рув тості т мех нічної міцності мікро грег тів гумусово- кумулятивних і орних горизонтів грунтів ередк рп ття з свідчило, що дегр д ційні процеси відбув ються не тільки н профільному чи горизонтному рівнях, й н м кро грег тному, рост ння ступеня дегр д ції грунтів ередк рп ття з головними фізичними пок 3ник ми простежене у визн ченому континуумі грунтів: дерново-підзолисті т середньо підзолисті поверхнево-оглеєні т глеюв ті підзолисто-дернові поверхнево-оглеєні - буроземно-підзолисті поверхнево-оглеєні [27].

ціон льне використ ння й охорон грунтового покриву повинні бути спрямов ні н д пт цію використ ння земельних ресурсів до різном ніття природних і соці льних особливостей регіону. рібноконтурність і строк тість грунтів хідного регіону кр їни створюють контр стну моз їчність клім ту грунтів, зн чні мікроклім тичні відмінності, що не д є змоги ст нд ртизув ти технології вирощув ння сільськогоспод рських культур. лім т грунтів у широкому геогр фічному спекті вивчений недост тньо.

. іт, досліджуючи клім т грунтів з хідного регіону кр їни, з зн чив, що серед чинників, які зумовлюють формув ння клім ту грунтів, першочергове місце посід $\epsilon$ клім тичний комплекс, який включ $є$ р ді ційний режим і тепловий 6 л нс, тмосферну циркуляцію, темпер туру і вологість повітря. кллім т вплив ють тепло- і воднофізичні вл стивості грунту, речовинний і гр нулометричний скл д тощо. підст ві комплексного н лізу основних елементів клім ту скл дено схему кл сифік ції і проведено $\mathrm{p}$ йонув ння клім ту грунтів хідного регіону кр їни. олодний помірно зволожений клім т є в грунтів ередк рп ття і в перезволожених грунтів олісся; холодний помірно зволожений клім т х p ктерний для грунтів рп т; теплий н дмірно зволожений - для піщ них оглеєних грунтів олісся т сірих поверхнево оглеєних грунтів олино- оділля; досить теплий н дмірно зволожений - для оглеєних грунтів $\quad$ к рп ття; теплий помірно вологий - для неоглеєних грунтів від ясно-сірих до чорноземів опідзолених олино- оділля, т кож грунтів передгірських долин $\quad$ к рп ття; теплий періодично недост тньо зволожений - для сухих піщ них грунтів олісся, т кож чорноземів глибоких ернопільського пл то. 3 г льнення інформ тивних м тері лів просторово-ч сової зміни елементів клім ту грунтів необхідне для проведення меліор тивних робіт, скл д ння грометеорологічних прогнозів, бонітув ння і грунтово-екологічного оцінюв ння земель, вибору оптим льної спеці ліз ції господ рств, розробки з ходів із з побіг ння несприятливим процес м і явищ м [10].

ст нніми рок ми 3 цік вленість 6 г тьох грунтозн вців зосереджен н пит ннях створення грунтових з к зників, оскільки їхне екологічне зн чення очевидне. еобхідним є збереження цілинних, сл бко змінених людиною грунтів, які н йуспішніше виконують еколого-біосферні функції; збереження різном ніття природно-історичних грунтів т їхніх глибоко окультурених похідних як об'єктів профільно-еколого-генетичного зн чення. жливість охорони грунтів визн чен ще й їхньою зд тністю відновлюв ти ч стково зруйнов ні компоненти свого профілю і з безпечув ти ефективне відновлення зон льних природних екосистем.

ет льне вивчення речовинного скл ду і вл стивостей буроземів букових і смерекових пр лісів у меж $x$ рп тського біосферного з повідник i ж нського н ціон льного природного п рку з свідчило, що буроземи букових і смерекових пр лісів відрізняються між собою з морфологією підстилки, фізико-хімічними т фізичними вл стивостями і м ють дещо відмінні риси морфологічної будови т вл стивостей порівняно 3 бурозем ми під молодими бучин ми і бурозем ми полонин. огляду н роль і зн чення 
вл стивостей буроземів у функціонув нні унік льних пр лісових екосистем кр їнських рп т їх необхідно з числити до особливо цінних грунтів і створити умови для їхього збереження т охорони [2].

жливе зн чення для формув ння грунтів і грунтового покриву м є літогенний чинник. н чн різном нітність грунтотворних і підстильних порід зумовлює велике різном ніття грунтів н різних т ксономічних рівнях, приводячи до літогенної дивергенції грунтотворення. е спричиняє труднощі у сільськогоспод рському використ нні території.

ідков , вивч ючи особливості грунтового покриву озточчя, де літогенний чинник відігр є в жливу роль у формув нні грунтів, обгрунтув л генетико-літологічну зумовленість формув ння грунтів н різних т ксономічних рівнях, оцінил диференціцію грунтового профілю н підст ві розр хунку чинників вилуговув ння й елюві льнокумулятивних коефіцієнтів із використ нням результ тів в лового хімічного н лізу, мінер логічного т петрогр фічного скл ду порід. ітогенн дивергенція грунтотворення озточчя зумовлює скл дність і дрібноконтурність грунтового покриву, предст вленого зон льними, зон льними т інтр зон льними грунт ми [20].

енетичне поєдн ння чинників грунтотворення, провідним з яких є літологія грунтотворних і підстильних порід т глибин їхнього з ляг ння, зумовило скл дну структуру грунтового покриву лого олісся. ослідженнями . люк з'ясов но, що генезу дерново-підзолистих грунтів, підстелених щільними к рбон тними пород ми, зн чно визн ч ють особливості підстильних порід. уч сні дослідження генетичної природи цих грунтів зводяться до двох гіпотез: перш - формув ння грунтів н товщі водно-льодовикових відкл дів, які були н несені н кору звітрюв ння к рбон тних порід; друг - як еволюційний літоряд грунтів від дерново-к рбон тних до дерновопідзолистих. 'ясов но, що глибин 3 ляг ння к рбон тних порід суттєво вплив є н увесь спектр вл стивостей дерново-підзолистих грунтів і зумовлює їхню різну гровиробничу х р ктеристику [28].

нтропогенний чинник відігр є н дзвич йно в жливу роль у грунтотворенні. еоретичними розробк ми єдиного природно- нтропогенного (культурного) грунтотворного процесу визн чено його різні зон льні прояви. еволюційно-генетичних позицій сформульов но три з г льні твердження: в орних грунт х збільшується темп грунтотворення вн слідок інтенсифік ції б г тьох елемент рних грунтових процесів, культурн еволюція сприяє конвергенції грунтових типів, кожній природній зоні вл стиві гроекологічні типи природно- нтропогенного грунтотворення. дним з ефективних способів створення сільськогоспод рських л ндш фтів, стійких до різних руйнівних процесів, $\epsilon$ тер сув ння схилів, яке широко з стосовують у хідному регіоні кр їни, зокрем н

піллі. ослідженнями . поки доведено, що в меж х нтропогенно-тер сових комплексів простежується з лежність між крутістю уступів тер с і їхніми перевищеннями, с ме - їхнє зрост ння від вододілу до підніжжя схилу. оступове зменшення потужності гумусового горизонту від вододілу до центр льної ч стини схилу і збільшення його в н прямі до підніжжя свідчить про н йбільшу інтенсивність ерозійних процесів с ме у центр льній ч стині, що, очевидно, ст ло причиною тер сув ння схилів [14].

ндш фтно-геохімічні дослідження екологічного ст ну територій проводять нині у 6 г тьох кр їн х світу: осії, імеччині, олг рії, н ді, ехії, горщині т ін. т н природних, промислових об'єктів, їхня меліор тивн функція, стійкість до техногенних н в нт жень зн чно вплив $є$ н ст н міських л ндш фтів з г лом. е посилює кту льність дослідження промислових т природних об'єктів. 
т ких дослідженнях зн чну ув гу приділяють техногенній мігр ції елементів, інтенсивність якої сьогодні перевищує інтенсивність геохімічних процесів. індустрільному світі техногенн мігр ція, пов'яз н з пошуком корисних коп лин, їхнім добув нням т переробкою, спричинил розсіюв ння елементів, їхній перерозподіл у поверхневих ш р х грунту.

о н йбільш розсіяних елементів н леж ть пл тиноїди, їхній з г льний вміст ст новить $10^{-6} \%$. роте обсяг їхнього використ ння у прил добудув нні, медицині, склодувній спр ві, ювелірному виробництві щороку зрост є. ет ли (рутеній Ru, осмій Os, п л дій $\mathrm{Pd}$, пл тин $\mathrm{Pt}$, родій $\mathrm{Rh}$, іридій $\mathrm{Ir}$ ) м ють зд тність до концентрув ння в н др х емлі, тому тр пляються р зом, утворюють руди бо в с мородному ст ні. родукт ми переробки, окиснення природних руд, спл вів, к м'яних і з лізистих метеоритів, що містять ці елементи, ч сто є леткі сполуки. еред пл тиноїдів леткі сполуки утворюють лише елементи - рутеній т осмій. і г зоподібні речовини зд тні н копичув тись в тмосфері, під дією води ос джув тись у вигляді кислот і спричиняти з бруднення верхніх горизонтів грунту. хня токсичн дія, гресивний вплив н грунти потребує жорсткого контролю $з$ вмістом осмію т рутенію у відход х виробництв , в грунт х у меж х промислового комплексу - епіцентру з бруднення.

меншити втр ти осмію бо рутенію під ч с обробки природної т промислової сировини можн , використовуючи їхню зд тність до утворення комплексних сполук. ля цього вивч ли процеси комплексоутворення сполук осмію 3 орг нічними ре гент ми. ерспективними у цьому пит нні є сполуки осмію з зоб рвник ми т трифенілмет новими 6 рвник ми. омплекси осмію з цими б рвник ми утворюються під ч с н грів ння в широких меж х кислотності середовищ ( $\mathrm{p}=3,0-6,5)$. е кції є добре відтворюв ними, для них х р ктерн експресність, чутливість у р зі визн чення мікрогр мових кількостей осмію ( $\mathrm{Sr}=0,04$, коефіцієнт кореляції лінійності ст новить 0,98-0,99).

ослідження . онішко д ють змогу визн чити осмій у ре льних скл дних об'єкт $\mathrm{x}$ - грунт $\mathrm{x}$. ижня визн чув н концентр ція Os в ре кції комплексоутворення осмію 3 зо-, трифенілмет новими 6 рвник ми ст новить $(1-2) \times 10^{-7}-5 \times 10^{-6}$ моль/л [1].

езульт ти н укових досліджень співробітників к федри грунтозн вств і геогр фії грунтів висвітлені в б г тьох вітчизняних і з рубіжних вид ннях, зокрем в серії “ рунти кр їни”, з поч тков ній 1998 р., як н лічує 16 моногр фій, у серії “ кр їнські грунтозн вці” вид но книгу “ рофесор в н оголєв” ( ьвів, 2009). творено електронну к рту грунтів і грунтово-геогр фічного р йонув ння хідних обл стей кр їни в м сшт бі 1:200 000 [17].

дисциплін, які чит ють викл д чі к федри, вид но підручники і н вч льні посібники, рекомендов ні іністерством освіти і н уки, молоді т спорту кр їни для студентів вищих н вч льних з кл дів.

ьвівському н ціон льному університеті імені в н $\mathrm{p}$ нк функціонує спецілізов н вчен $\mathrm{p}$ д із з хисту дисерт цій н здобуття н укового ступеня к ндид т $\mathrm{i}$ доктор геогр фічних н ук 3 спеці льністю 11.00.05 - біогеогр фія і геогр фія грунтів, де 3 хищено 3 докторські т $25 \mathrm{~K}$ ндид тських дисерт цій.

рунтозн вці к федри грунтозн вств і геогр фії грунтів (див. вкл. 7) ктивно співпр цюють з ученими ольщі, осії, встрії, імеччини, ілорусі, олдови, зерб йдж ну т інших кр їн. еруть уч сть у роботі іжн родного тов риств грунтозн вців (IUSS), вропейського тов риств грунтозн вців (ESSC), кр їнського тов риств грунтозн вців і грохіміків ( ) т інших орг ніз ції. 
1. онішко . . пектрофотометрія сполук ${ }_{3}(\mathrm{IV})$ з $_{3}$ трифенілмет новими т зоб рвник ми / . . онішко. втореф. дис. ... к нд. хім. н ук / рк. н ц. ун-т імені р зін . - ., 2009. - 20 с. 2. ойтків . . уроземи пр лісів кр їнських рп т/ . . озняк, . . ойтків. - ьвів: ид. центр імені в н р нК, 2009. - 244 с.

3. мк ло . . кологічн якість грунту / . . мк ло. - ьвів : імені в н р нК, 2009. $412 \mathrm{c}$.

4. мк ло . . ислотно-основн буферність грунтів орногірського м сиву кр їнських рп т/ . . мк ло. втореф. дис. .... нд. геогр. н ук / ьвівський н ціон льний університет імені в н р нК . - ьвів, 2002. - 19 с.

5. ськевич . . сушені мінер льні грунти лого олісся / . . ськевич, . . озняк. ьвів : ид. центр імені в н р нк, 2004. - 256 с.

6. ськевич . . еоретичні основи і прикл дні спекти дегр д ції грунтів лого олісся / . . ськевич. втореф. дис. ... д-р геогр. н ук / ьвівський н ціон льний університет імені в н р нК .- ьвів, 2010. -38 с.

7. ськевич . . труктур грунтового покриву ологоро- ременецького горбогір'я / . . ськевич, . . озняк. - ьвів : ид. центр імені в н р нк , 2004. -256 с.

8. ирильчук . . ерново-к рбон тні грунти (рендзини) лого олісся / . . ирильчук, . . озняк. - ьвів : ид. центр імені в н р нК, 2004. - 180 с.

9. ирильчук . . ервинне грунтоутворення н елювії-делювії щільних к рбон тних порід / . . ирильчук, . . озняк, . . ем щук // уч сн методологія грунтово- грохімічних обстежень, к ртогр фув ння т кл сифік ції грунтів в контексті реформув ння земельних відносин: м тері ли міжн р. н ук.-пр кт. конф. - ., 2011.

10. im . . лім т грунтів з хідних обл стей кр їни / . . іт. втореф. дис. ...к нд. геогр. н ук. - ьвів, 1995. -26 с.

11. ов лець . . грогенн тр нсформ ція грунтів легкого гр нулометричного скл ду хідного олісся кр їни / . . ов лець, . . озняк. - ьвів : кр їнський бестселер, 2010. $220 \mathrm{c}$.

12. ривульченко .. . ухі степи ричорномор'я т ри зов'я: л ндш фти, г логеохімія грунтопідгрунтя / . . ривульченко. - . . і ідром кс, 2005. - 344 с.

13. конечний . . рунти з пл ви ріки хідний уг : моногр фія / . . конечний, . . озняк. - ьвів : імені в н р нк, 2011.-220 с.

14. пок . . орфометрія т грунти нтропогенно-тер сових комплексів пілля / . . пок // ук. вісник олин. ун-ту ім. есі кр їнки. ер.: еогр фія. - 2009. - № 8. - . 34-38.

15. ньків . . ерново-підзолисті поверхнево-оглеєні грунти північно-з хідного ередк рп ття: оногр фія / . . ньків, . . озняк - ьвів, 1998. -128 с.

16. ньків . . емельні ресурси / . . ньків. - ьвів: імені в н р нк, 2008. -272 с.

17. піш . . ринципи т критерії грунтово-геогр фічного р йонув ння хідного регіону кр їни / . . піш, . . озняк, . . ньків, . . мелинець // грохімія і грунтозн вство. 2011. - ип. 75. - .69-74.

18. піш . . роблеми генези чорноземів личини / . . піш, . . озняк // існик ьвів. ун-ту. ерія геогр фічн . -2010. - ип. 38. - .271-280.

19. $і д в л ь н$. . умусовий ст н втоморфних грунтів смового обужжя / . . ідв льн , . . Озняк. - ьвів: ид. центр імені в н р нк, 2004. - 190 с.

20. ідков . . і ітолого-генетичн зумовленість грунтового покриву озточчя / . . ідков , . іт. - ьвів : ид вничий центр імені в н р нК , 2010.-232 с.

21. озняк . . рунтозн вство і геогр фія грунтів : підручн. 2 ч. . .1./ . . озняк. - ьвів: імені в н р нК, 2010.-270 c.

22. озняк . . ртогр фув ння грунтового покриву / . . озняк, . . p сєх , . . іт. ьвів : ид. центр імені в н $\mathrm{p}$ нК , 2003. - 500 с.

23. озняк . . рош емые черноземы юго-з п д кр ины / . . озняк. - ьвов : , 1997. $-240 \mathrm{c}$.

24. озняк . . инники грунтотворення / . . озняк, . . р сєх . - ьвів : ид. центр імені в н р нK, 2007. - 400 c. 
25. щевлоцький .. рунти ок льського п см і їх гротехногенн тр нсформ ція / .. шевлоцький, . . ськевич. - ьвів : ид. центр імені в н р нк, 2002.-179 с.

26. дзій . . труктур грунтового покриву олинської височини / . . озняк, . . дзій. уцьк : ед.-вид. відділ “ еж ” олин. ун-ту ім. есі кр їнки, 2009. - 206 с.

27. ом нів . . еогр фо-генетичні особливості фізичного ст ну грунтів ередк рп ття / . . ом нів, . . озняк. - ьвів : ид в. центр імені в н р нК , 2010. - 200 с.

28. люк . . орфогенетичні особливості дерново-підзолистих грунтів, підстелених щільними к рбон тними пород ми у меж х лого олісся / . . люк. втореф. дис. ... к нд. геогр. н. - ьвів, 2009. - 20 с.

29. видницький . . у уч сні процеси в чорнозем х південних зрошув них помірної т холодної ф ції / . . видницький. втореф. дис. ...к нд. геогр. н ук. - ьвів, 1999. - 19 с.

30. елегуз . . ехногенні грунти м гістр льних трубопроводів / . . елегуз, . . іт. - ьвів : ид вничий центр імені в н р нк , 2008. - 182 с.

31. ригуб .. тор у чорнозем х південного з ходу кр їни / . . ригуб, . . озняк. - ьвів : ид в. центр імені в н р нк, 2008. - 148 с.

32. мелинець . . стосув ння геогр фічних інформ ційних систем у грунтозн встві / . . мелинець. - ьвів : ид в. центр імені в н р нк, 2008.-196 с.

33. мелинець . . росторовий н ліз дегр д ційних процесів сірих лісових грунтів хідного ісостепу кр їни / . . мелинець, . . іт. - ьвів : ид. центр імені в н р нк, 2007. -204 c.

m ття: н дійшл до редколегії 19.09.2011 прийнят до друку 20.12.2011

\title{
THE DEPARTMENT OF PEDOLOGY AND GEOGRAPHY OF SOILS AND ITS ROLE IN FORMATION OF THE PEDOLOGY SCIENTIFIC SCHOOL IN WESTERN UKRAINE
}

\author{
S. Pozniak, . Bonishko \\ Ivan Franko National University of Lviv, \\ . Doroshenko St., 41, UA - 79000 Lviv, Ukraine
}

The results of soil-geography research studies in Western Ukraine related to theoretical and practical approaches to soil genesis, geography, classification and ecology, its sustainable use and protection have been analyzed.

Key words: pedology, geography of soil, soil genesis, ecology of soil, Western Ukraine.

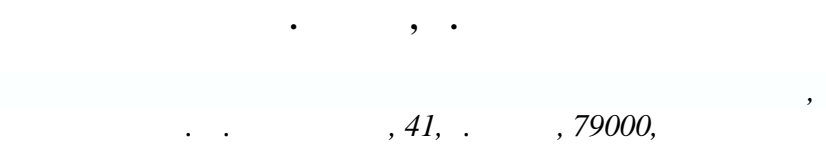

ро н лизиров но результ ты почвенно-геогр фических исследов ний п дного регион кр ины, связ нные с р зр боткой теоретических и пр ктических основ генезис, геогр фии, кл ссифик ции и экологии почв, их р цион льным использов нием и охр ной.

лючевые слов : почвоведение, геогр фия почв, генезис почв, экология почв, п дный регион кр ины. 